\title{
Stress-Strain Relationship of High-Performance Fiber-Reinforced Concrete using Silica Fume and Steel Fiber
}

\author{
Krisnamurti $^{\mathrm{a}}$, A Soehardjono ${ }^{\mathrm{b}}, \mathrm{A} \mathrm{Zacoeb}^{\mathrm{b}}, \mathrm{A} \mathrm{Wibowo}^{\mathrm{b}}$ \\ ${ }^{a}$ Department of Civil Engineering, Faculty of Engineering, University of Jember, Jember 68121, Indonesia \\ E-mail: murti_krisna.teknik@unej.ac.id \\ ${ }^{b}$ Department of Civil Engineering, Faculty of Engineering, University of Brawijaya, Malang 65145, Indonesia \\ E-mail:agoessmd@ub.ac.id; zacoeb_a@yahoo.com; ariwibowo@ub.ac.id
}

\begin{abstract}
Disaster mitigation in the world of civil engineering can do by improving the performance of construction materials using High-Performance Fiber-Reinforced Concrete (HPFRC). The increasing performance of concrete materials positively affects the physical and mechanical properties of the concrete produced, including the modulus of elasticity. Many equations develop to calculate the distribution of stress-strain of concrete material, such as the Madrid Parabola Formula, Desay \& Khrisnan Formula, Majewski Formula, Wang \& Hsu Formula, and Saenz Formula. The purpose of this study is to investigate a stress-strain distribution equation and the elastic modulus of elasticity of HPFRC using Portland Pozzolana Cement (PPC) with variations in the composition of silica fume and steel fiber and also investigate the formula of the HPFRC stress-strain distribution. The study conduct using $\phi 15 \mathrm{~cm} x 30$ cm cylindrical specimens. The materials are PPC, sand, gravel, water, silica fume additives, superplasticizers, and Dramix @ 3D steel fiber. Silica fume used varies from $0.0 \%$ to $15.0 \%$ of the weight of cement. While the steel fiber varies from $0.2 \%$ to $1.4 \%$ of the volume of the concrete mixture. The compressive strength test carries out refers to ASTM C39/C39M-03, 2003. The stress-strain relationship of HPFRC is obtained from the axial deformation measurement using an extensometer. The results of the study compare with some well-known stress-strain relationship equation. From this study, the stress-strain relationship formula of Desay-Khrisnan is rather suitable for the concrete with W/B ratio variation, but not suitable for silica fume and steel fiber content variation.
\end{abstract}

Keywords - HPFRC; modulus of elasticity; steel fiber; silica fume.

\section{INTRODUCTION}

Natural hazards affect most areas in Indonesia, such as volcano eruption, earthquakes (such as Papua, Celebes, Java, Sumatera, Bali, and Nusa Tenggara), large surges and high winds occurring in the coastal areas as well as the flood in the cities and rural areas. The earthquake conditions destroyed the infrastructure, which uses heavy materials. The living creatures and assets will threaten if the collapse of infrastructure happens. Therefore, the choice of technology and materials constructions will be needed to become the bases for prevailing multi-hazard conditions in the region; hence, everything which constructed should remain safe under the natural hazards when it strikes the area [1].

One of the most significant infrastructure safety problems in the world today is in reinforced concrete buildings designed and built before the introduction of provisions for a seismic design for ductile responses. Therefore, the collapse assessment technology for existing concrete buildings recognizes as a high priority to improve. The need to develop because of: (1) limited ability to predict collapse thresholds of old reinforced concrete structures; (2) Substantial loss of life and significant economic losses can result from total collapse due to building failure [2]. Meanwhile, Mitigation to improve the safety of new infrastructure against disasters is also ongoing. The Mitigation carried out through various studies on the behavior of building structural elements, material properties, as well as improving the performance of construction materials. The increasing performance of concrete constituent materials positively affects the physical and mechanical properties of the concrete.

HPFRC, as an advanced material, has developed and increased in various infrastructure projects. High strength concrete with the compressive strength above $55 \mathrm{MPa}$ [3] considers as one type of High-Performance Concrete [4]. Unreinforced concrete has weak tensile strength and an inadequate strain capacity at fracture. Adding reinforcing bars will cope with this deficiency. To optimize performance, reinforcing steel is specifically located in the structure. Fibers are usually distributed disordered throughout the 
matrix of the concrete. Steel fiber often uses in constructional practice with ordinary reinforcement [5] because of its flexibility in methods of construction.

This study explains 1) The development of the compressive stress-strain distribution of cylindrical test specimens; 2) The modulus of elasticity behavior of highperformance concrete. This study will explain the symptoms or rules of porosity control, reduction in grain size, as well as control of the homogeneity of the concrete ingredient to increase the strength of hydrated cement paste to form highperformance concrete materials.

The equations to calculate the stress-strain distribution of concrete material have been developed [6]. Hognestad has develops a stress-strain distribution equation in the transverse cross-section of the plate where the maximum bending moment less than the need to form a flexural crack. The equation is known as the formula of parabola Madrid. The strain distribution varies linearly along with the thickness of the plate. The resulting stress distribution is determined using the stress-strain relationship given by equation [7]:

$\sigma_{c}=f_{c}^{\prime}\left[\frac{2 \varepsilon_{c}}{\varepsilon_{0}}-\left(\frac{\varepsilon_{c}}{\varepsilon_{0}}\right)^{2}\right] \mathrm{MPa}$,

if $\varepsilon_{c} \leq \varepsilon_{0}$

and $\sigma_{c}=f_{c}^{\prime}-0,83 f_{c}^{\prime}\left(\varepsilon_{c}-\varepsilon_{0}\right) \mathrm{MPa}$,

if $\varepsilon_{0}<\varepsilon_{c} \leq \varepsilon_{u}$

with $\sigma_{c}=$ compressive stress in concrete; $\varepsilon_{c}=$ strain in concrete; $f_{c}^{\prime}$ is the maximum compressive strength of $\phi 15$ $\mathrm{cm}$ by $30 \mathrm{~cm}$ cylinders of similar dimensions; $\varepsilon_{0}=0,002$, dan $\varepsilon_{u}=0,0038$.

Desay and Krishnan proposed another simple form equation for a concrete stress-strain relationship [8].

The general form of the equation of the serpentine curve proposed by Carreira and Chu to explain the strain-stress relationship of unconfined concrete is in the form:

$\frac{f_{c}}{f_{c}^{\prime}}=\frac{\beta\left(\frac{\varepsilon_{c}}{\varepsilon_{0}}\right)}{\beta-1+\left(\frac{\varepsilon_{c}}{\varepsilon_{0}}\right)^{\beta}}$
and $\beta=\frac{1}{1-\frac{f_{c}^{\prime}}{\varepsilon_{0} E_{i t}}}$

for $\beta \geq 1.0$ and $\epsilon \leq \epsilon_{u}$

where $\beta$ is a material parameter that depends on the shape of the stress-strain diagram and the $E_{i t}$ is the initial tangential modulus. For the equation developed by Desay and Krishnan, the value of $\beta$ is 2. Moldovan [8] and Kmiecik [6] summarize some equations about concrete stress-strain relationships.

Modulus of elasticity is the ratio of stress to corresponding strain below the proportional limit. Chord modulus of elasticity is the slope of the chord drawn between any two specified points on the stress-strain curve below the elastic limit of the material [10]. The modulus of elasticity calculate using equation [11]:

$E=\left(S_{2}-S_{1}\right) /\left(\epsilon_{2}-\epsilon_{1}\right)$

where,
$\mathrm{E}=$ chord modulus of elasticity $(\mathrm{MPa})$

$S_{2}=$ stress corresponding to $40 \%$ of the ultimate load (MPa)

$S_{1}=$ stress corresponding to a longitudinal strain, $\epsilon_{1}$, of 50 millionths (MPa)

$\epsilon_{2}=$ longitudinal strain produced by stress $S_{2}$.

$\epsilon_{1}=0.000050$

If the strain of concrete approaches the value of 0.002 or if the concrete compressive stress cannot increase again because of concrete cracking, so the modulus of elasticity is determining using the ultimate load. The strain rate, the quality of the cement matrix, the aggregates characteristics, the composition of steel fiber, and silica fume profoundly influence the relationship of the compressive stress-strain of HPFRC [9]. This study aims to investigate the modulus of elasticity behavior and develop the stress-strain distribution formula of HPFRC that uses PPC material with variations in the composition of silica fume and steel fiber.

\section{MATERIAL AND METHOD}

The standard for normal and heavyweight concrete selection proportions [12], which has been adopted in SNI $7656: 2012$ [13], was used as a reference to the high strength concrete mix design. This research used equipment: 1) cylinder mold, diameter $150 \mathrm{~mm}$, height $300 \mathrm{~mm}$; 2) compactor stick, diameter $16 \mathrm{~mm}$, length $600 \mathrm{~mm}$, with rounded edges; 3 ) concrete mixer with capacity of 275 liters; 4) the scales with an accuracy of $0.3 \%$ by weight of the sample; 5) concrete vibrator; 6) a set of capping tools; 7) additional equipment: buckets, shovels, spoons, levelers, and trays; 8) a set of slump checking devices; 9) a set of weighing devices for concrete contents. The study began with testing the compressive strength of a concrete cylinder with a water/binder ratio between 0.20 to 0.32 . In order to get high-strength concrete with compressive strength exceeding $55 \mathrm{MPa}$, this test will get the most optimal water/binder ratio. Furthermore, the research conduct by testing changes in silica fume levels. The percentage of silica fume against PPC weight shown in Table I.

TABLE I

Percentage of Silica Fume Against Cement Weight

\begin{tabular}{|l|c|c|c|c|}
\hline & $\begin{array}{c}1 \text { st } \\
\text { content }\end{array}$ & $\begin{array}{c}2 \text { nd } \\
\text { content }\end{array}$ & $\begin{array}{c}3 \text { rd } \\
\text { content }\end{array}$ & $\begin{array}{c}4 \text { th } \\
\text { content }\end{array}$ \\
\hline Silica Fume & $0 \%$ & $5 \%$ & $10 \%$ & $15 \%$ \\
\hline
\end{tabular}

The compressive strength test carried out refers to the Standard test method for compressive strength of cylindrical concrete specimens [14] and the concrete compressive strength testing methods [15]. Three pieces of concrete cylinders $\phi 150 \mathrm{~mm} \times 300 \mathrm{~mm}$ uses as the test specimens. In addition to compressive strength testing, the longitudinal deformation measurements also performed. The universal testing machine (UTM) with $2000 \mathrm{kN}$ capacity was used as concrete compressive strength test equipment, as shown in Fig. 1. The study used a cylindrical specimen $\phi 15 \mathrm{~cm}$ x 30 $\mathrm{cm}$. Axial deformation measurements perform using an extensometer consisting of 2 circular elements, a locking rod, an indicator bar, and a dial gauge.

The study used Dramix ${ }^{\circledR}$ 3D steel fiber, which has a tensile strength of $\mathrm{Rm}$, nom $=1,225 \mathrm{MPa}$ with a tolerance of 
$+7.5 \%$. Length $(\mathrm{l})=60 \mathrm{~mm}$, Young's modulus $=210,000 \mathrm{~N}$ $/ \mathrm{mm}^{2}$. Diameter $(\mathrm{d})=0.75 \mathrm{~mm}$. Aspect ratio $(1 / \mathrm{d})=80$. Minimum usage $=10 \mathrm{~kg} / \mathrm{m}^{3}$ [16]. The end hook of Dramix ${ }^{\circledR} 3 \mathrm{D}$ ensured the expected fiber pull-out.
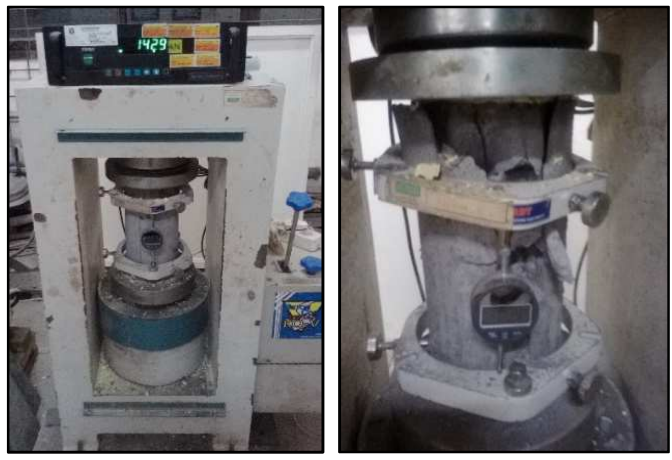

Fig. 1 The compressive strength test setting of the concrete cylinder.

Dramix ${ }^{\circledR} 3 \mathrm{D}$ produced concrete ductility through slow deformation of the hook during the pull-out process, and not by the ductility of the wire itself [17]. The treatment variation manifested in fiber proportions difference by random arrangement. The high-performance concrete mix tested consisted of PPC, sand, gravel, water, silica fume, and polycarboxylate-based superplasticizer. The use of fiber proportion shown in Table II.

\section{TABLE II}

STEEL FIBER PROPORTION

\begin{tabular}{|c|c|c|c|c|c|c|}
\hline Fiber & Unit & $\begin{array}{l}\text { FRC- } \\
1\end{array}$ & $\begin{array}{l}\text { FRC- } \\
2\end{array}$ & $\begin{array}{l}\text { FRC- } \\
3\end{array}$ & $\begin{array}{l}\text { FRC- } \\
4\end{array}$ & $\begin{array}{l}\text { FRC- } \\
5\end{array}$ \\
\hline \multirow{2}{*}{$\begin{array}{l}\text { Steel } \\
\text { Fiber } \\
\text { Dramix } \\
\text { @ } 3 D\end{array}$} & $\mathrm{Kg} / \mathrm{m}^{3}$ & $\begin{array}{l}4.8 \\
\mathrm{~kg} / \mathrm{m}^{3}\end{array}$ & $\begin{array}{l}10 \\
\mathrm{~kg} / \mathrm{m}^{3}\end{array}$ & $\begin{array}{l}15 \\
\mathrm{~kg} / \mathrm{m}^{3}\end{array}$ & $\begin{array}{l}24 \\
\mathrm{~kg} / \mathrm{m}^{3}\end{array}$ & $\begin{array}{l}33.6 \\
\mathrm{~kg} / \mathrm{m}^{3}\end{array}$ \\
\hline & $\begin{array}{l}\% \\
\text { concrete } \\
\text { volume }\end{array}$ & $0.2 \%$ & $0.4 \%$ & $0.6 \%$ & $1.0 \%$ & $1.4 \%$ \\
\hline
\end{tabular}

The study used Dramix ${ }^{\circledR}$ 3D steel fiber, which has a tensile strength of Rm, nom $=1,225 \mathrm{MPa}$ with a tolerance of $+7.5 \%$. Length $(1)=60 \mathrm{~mm}$. Young's modulus $=210,000 \mathrm{~N}$ $/ \mathrm{mm}^{2}$. Diameter $(\mathrm{d})=0.75 \mathrm{~mm}$. Aspect ratio $(\mathrm{l} / \mathrm{d})=80$. Minimum usage $=10 \mathrm{~kg} / \mathrm{m}^{3}$ [16]. The end hook of Dramix ${ }^{\circledR} 3 \mathrm{D}$ ensured the expected fiber pull-out. Dramix ${ }^{\circledR}$ 3D produced concrete ductility through slow deformation of the hook during the pull-out process, and not by the ductility of the wire itself [17]. The treatment variation manifested in fiber proportions difference by random arrangement. The high-performance concrete mix tested consisted of PPC, sand, gravel, water, silica fume, and polycarboxylate-based superplasticizer. The use of fiber proportion shown in Table II.

\section{RESULTS AND DISCUSSION}

Fig. 2 shows the condition of the cylindrical specimen after the compressive strength test. It shows that the collapse of the cylinder tends to have a fracture pattern in the form of fractional edges, while the upper center remains intact.

The process of compressive strength testing, the relationship between compressive strength and strain occurs on the cylinder specimens. Fig. 3 shows the relationship between high-performance concrete axial stress-strain based on the $\mathrm{W} / \mathrm{B}$ ratio.

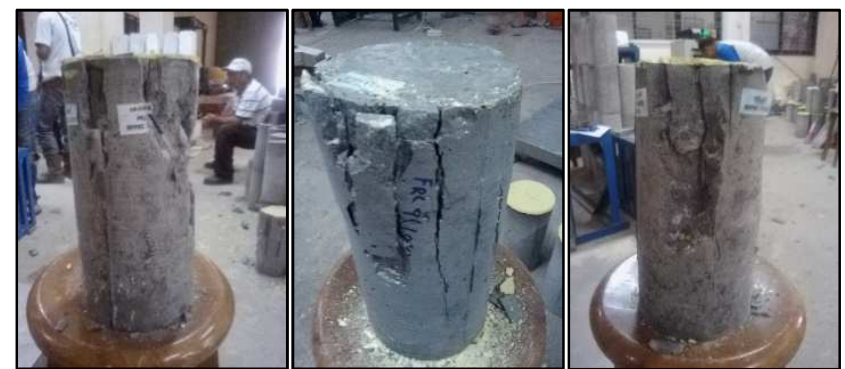

Fig. 2 The crack pattern of $\phi 15 \mathrm{~cm}$ x $30 \mathrm{~cm}$ cylinder specimen

According to the six $\mathrm{W} / \mathrm{B}$ ratios tested, the compressive strength of cylindrical specimens with the W/B ratio of 0.23 is capable of producing the highest concrete compressive strength, which is $56.57 \mathrm{MPa}$. The W/B ratios between 0,23 to 0.32 show that the pattern of stress-strain relationship behavior indicates almost the same response. That is, there is a linear relationship, which followed by a nonlinear line after cracks begin on the test object. However, for the W/B ratio of 0.20 , the pattern of the relationship looks poor.

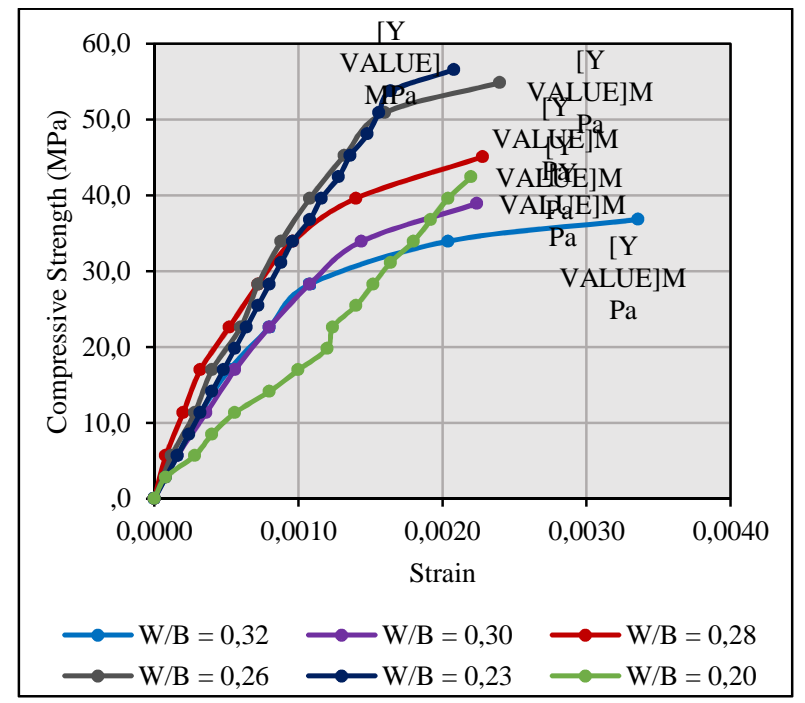

Fig. 3 The stress-strain correlation in the $\phi 15 \mathrm{~cm}$ x $30 \mathrm{~cm}$ cylinder testing with a variation of $\mathrm{W} / \mathrm{B}$ ratio.

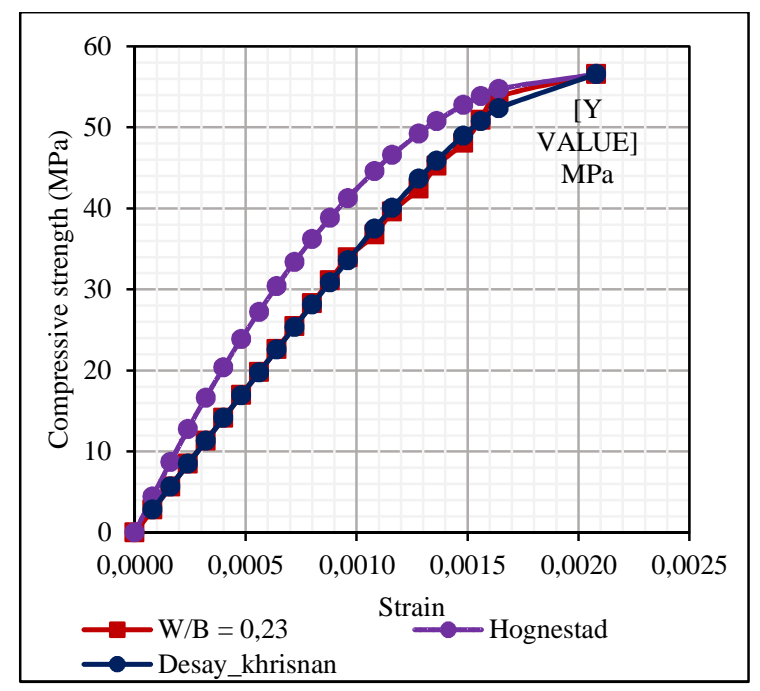

Fig. 4 The comparison of stress-strain correlation in W/B ratio $=0.23$ of the $\phi 15 \mathrm{~cm} \times 30 \mathrm{~cm}$ cylinder testing with stress-strain correlation using Hognestad and Desay_Khrisnan. 
The connection is related to the casting process of test specimens that are experiencing difficulties due to the low workability of the concrete mixture. According to the stressstrain relationship in testing variations of the W/B ratio, the average compressive strength for high-performance concrete of $56.57 \mathrm{MPa}$ with the W/B ratio of 0.23 fulfills the criteria of high strength concrete, and it easy to do a casting.

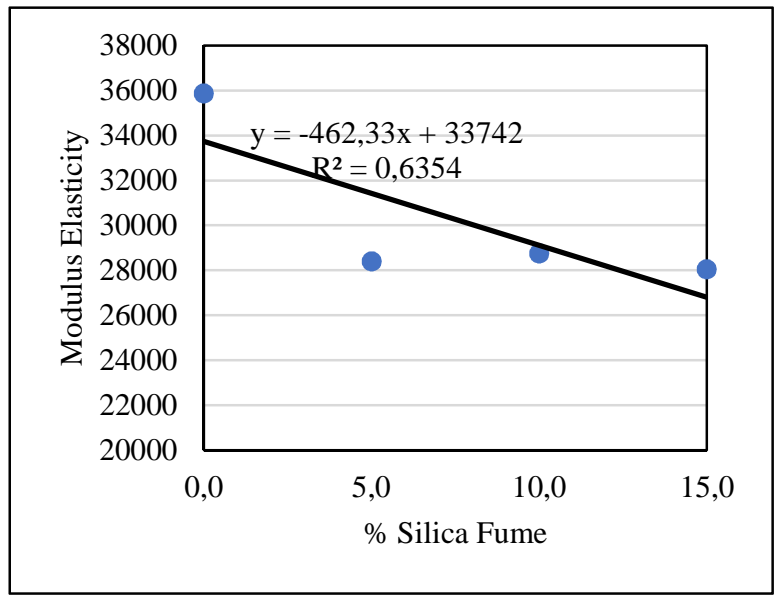

Fig. 5 The relationship of modulus of elasticity and silica fume (SF) content of $\phi 15 \mathrm{~cm}$ x $30 \mathrm{~cm}$ cylindrical specimens
Furthermore, the stress-strain relationship diagram for concrete with a compressive strength of $56.57 \mathrm{MPa}$ when evaluated with some equations that have been formulated by Hognestaad and Desay \& Khrisnan, shows satisfying conformity, as shown in Fig. 4. Modulus of elasticity for each water content shown in Fig. 5. The correlation between the W/B ratio with the modulus of elasticity shows a nonlinear relationship shown by the polynomial equation $\mathrm{Y}=$ $-3.10^{6} \mathrm{X}^{2}+2.10^{6} \mathrm{X}-199437$

\section{A. Effect of Silica Fume Composition on the Mechanical Properties of High-Performance Concrete}

The equation (4) calculate the modulus of elasticity of high-performance fiber-reinforced concrete (HPFRC) [18]:

$E=3320 \sqrt{f c^{\prime}}+6900$

as the result of research by Graybeal \& Davis[19] and Noguchi et al. [20]. The values of E and fc' are expressed in $\mathrm{MPa}$ units. Fig. 6. shows the stress-strain relationship that occurs during the compressive strength test of the cylinder $\phi 15 \mathrm{~cm} \times 30 \mathrm{~cm}$ according to the silica fume content. Then using the data in Table III, the average modulus of elasticity of high-performance concrete with silica fume content varies according to ASTM C 469-02 (2002) is 30,274.35 MPa.

TABLE III II

Modulus of Elasticity of High STRENGTH CONCRETE With COMPOSITION VARIATION OF SiLICA FuME

\begin{tabular}{|c|c|c|c|c|c|c|c|}
\hline \multirow{3}{*}{ Description } & \multicolumn{3}{|c|}{ Compressive Strength } & \multicolumn{3}{|c|}{ Strain } & \multirow{2}{*}{$\begin{array}{c}\text { Modulus of Elasticity } \\
\text { ( E ) }\end{array}$} \\
\hline & ultimate & $\mathrm{S}_{2}$ & $\mathrm{~S}_{1}$ & ultimate & $\varepsilon_{2}$ & $\varepsilon_{1}$ & \\
\hline & (MPa) & (MPa) & $(\mathrm{MPa})$ & - & - & - & (MPa) \\
\hline SF 0\% & 53.76 & 21.50 & 1.41 & 0.0021 & 0.0006 & 0.00005 & $35,873.02$ \\
\hline SF $5 \%$ & 65.08 & 26.03 & 1.77 & 0.0020 & 0.0009 & 0.00005 & $28,410.17$ \\
\hline SF $10 \%$ & 73.56 & 29.43 & 1.18 & 0.0020 & 0.0010 & 0.00005 & $28,764.82$ \\
\hline SF $15 \%$ & 65.08 & 26.03 & 1.18 & 0.0020 & 0.0009 & 0.00005 & $28,049.38$ \\
\hline & & & & & & & $30,274.35$ \\
\hline
\end{tabular}

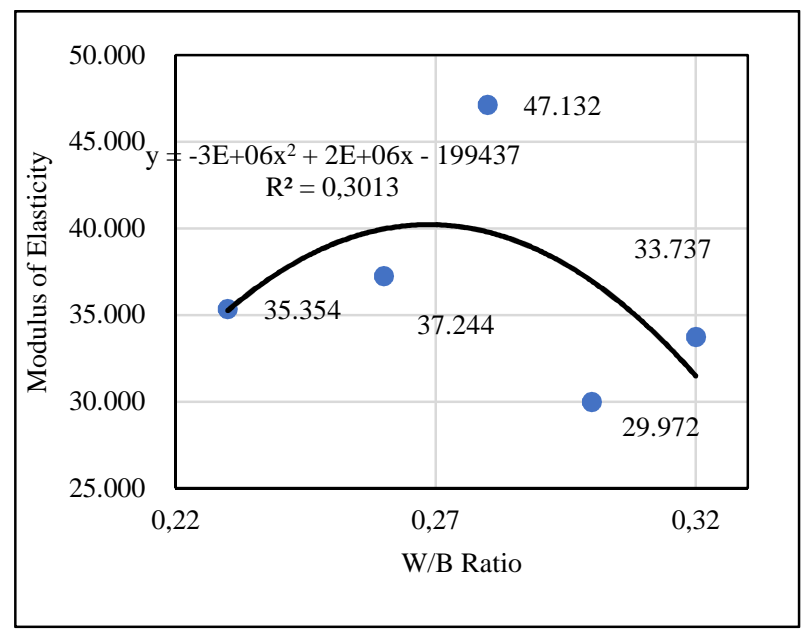

Fig. 6 The stress-strain correlation in $\phi 15 \mathrm{~cm}$ x $30 \mathrm{~cm}$ cylinder testing with a variation of $\mathrm{W} / \mathrm{B}$ ratio.

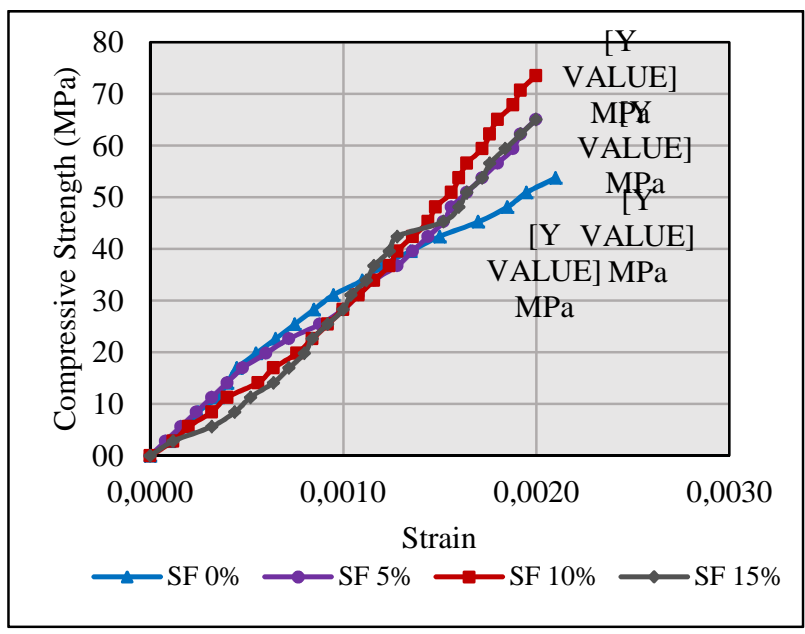

Fig. 7 The relationship of compressive strength-strain of high-performance concrete on $\phi 15 \mathrm{~cm}$ x $30 \mathrm{~cm}$ cylinder test using a variation of silica fume (SF) 


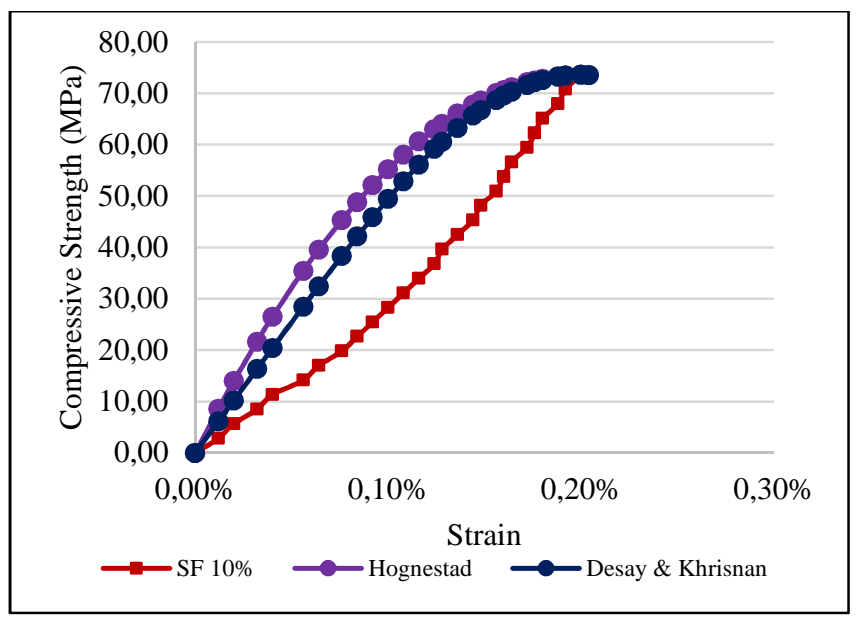

Fig. 8 The comparison of stress-strain correlation in $10 \%$ silica fume of $\phi 15$ $\mathrm{cm}$ x $30 \mathrm{~cm}$ cylinder testing with stress-strain correlation using Hognestad and Desay_Khrisnan.

\section{B. The Mechanical Properties of High-Performance Concrete with Steel Fiber}

The relationship of stress-strain from the concrete compressive strength test results with variations in steel fiber content is shown in Fig. 9. The higher of the steel fiber content used, the better the compressive strength values obtained. Furthermore, Fig. 10 shows the stress-strain relationship behavior for the $1.4 \%$ steel fiber content compared to calculations using the Hognestaad and the Desay \& Khrisnan equations.

The modulus of elasticity of high-performance fiber concrete with content variations of steel fiber shown in Table IV.

The relationship between variations in fiber content with the modulus of elasticity of high-performance fiber concrete can arrange in the form of diagrams, as shown in Fig. 11. The equation obtained from this relationship is $\mathrm{y}=$ $1039464.16 x+26488.64$ with a value of $R^{2}=0.51$. The addition of steel fiber content affects the increase of the modulus of elasticity of high-performance fiber concrete.

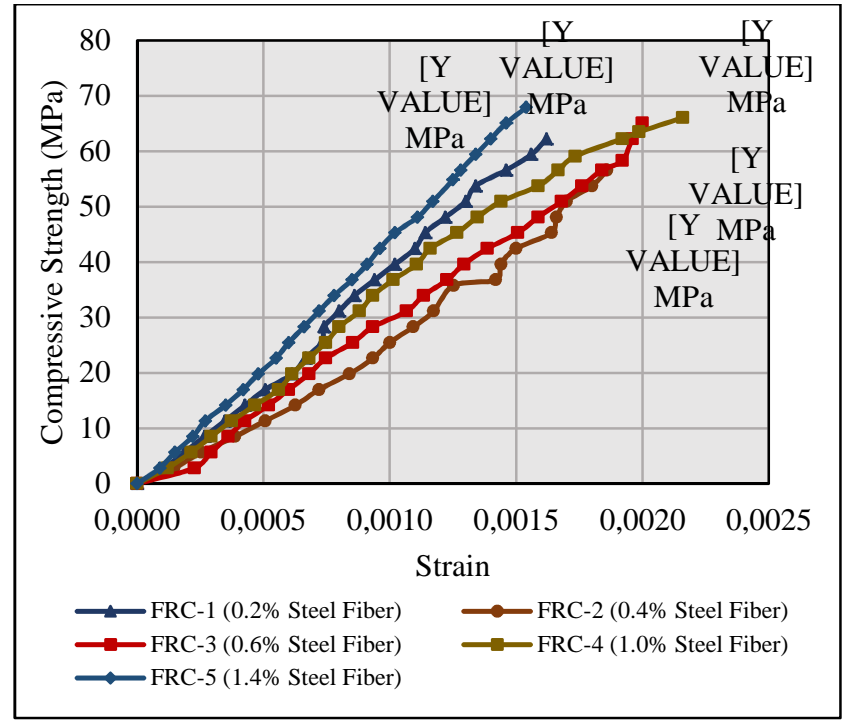

Fig. 9 The relationship of compressive strength-strain of high-performance concrete on $\phi 15 \mathrm{~cm}$ x $30 \mathrm{~cm}$ cylinder test using a variation of steel fiber Dramix@3D

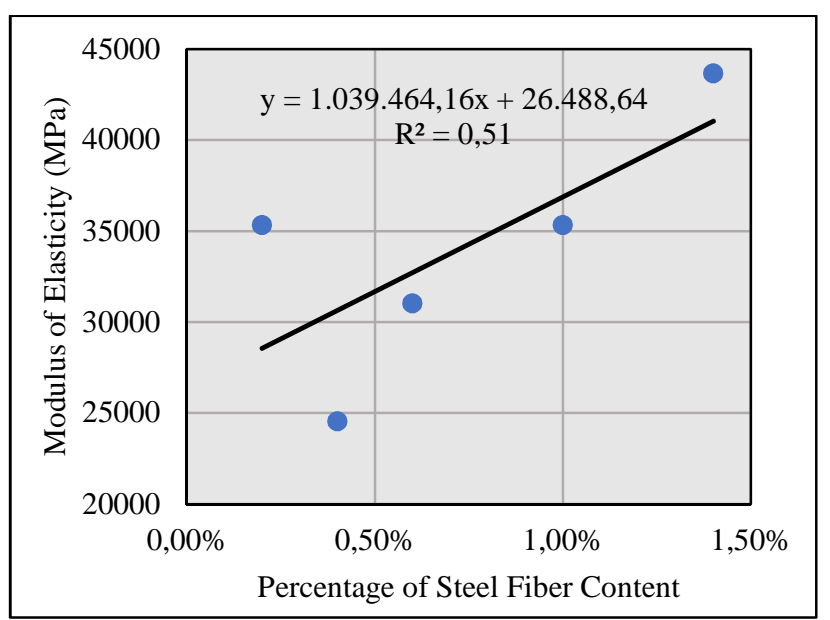

Fig. 10 The relationship of modulus of elasticity and steel fiber content of $\phi 15 \mathrm{~cm}$ x $30 \mathrm{~cm}$ cylindrical specimens.

TABLE IV

Modulus Of Elasticity Of High Strength CONCRETE With Composition Variation Of STEel Fiber

\begin{tabular}{|c|c|c|c|c|c|c|c|}
\hline \multirow{3}{*}{ Description } & \multicolumn{3}{|c|}{ Compressive Strength } & \multicolumn{3}{|c|}{ Strain } & \multirow{2}{*}{$\begin{array}{l}\text { Modulus of Elasticity } \\
\text { ( E ) }\end{array}$} \\
\hline & ultimate & $\mathrm{S}_{2}$ & $\mathrm{~S}_{1}$ & ultimate & $\varepsilon_{2}$ & $\varepsilon_{1}$ & \\
\hline & $(\mathrm{MPa})$ & $(\mathrm{MPa})$ & $(\mathrm{MPa})$ & - & - & - & $(\mathrm{MPa})$ \\
\hline FRC-1 $(0,2 \%)$ & 62.25 & 24.90 & 1.33 & 0.0016 & 0.0007 & 0.00005 & $35,325.39$ \\
\hline FRC-2 $(0,4 \%)$ & 56.59 & 22.64 & 0.96 & 0.0019 & 0.0009 & 0.00005 & $24,532.97$ \\
\hline FRC-3 $(0,6 \%)$ & 65.08 & 26.03 & 0.62 & 0.0020 & 0.0009 & 0.00005 & $31,008.79$ \\
\hline FRC-4 $(1,0 \%)$ & 66.10 & 26.44 & 1.18 & 0.0022 & 0.0008 & 0.00005 & $35,326.87$ \\
\hline FRC-5 $(1,4 \%)$ & 67.91 & 27.16 & 1.57 & 0.0015 & 0.0006 & 0.00005 & $43,669.87$ \\
\hline
\end{tabular}

\section{CONCLUSION}

This research investigated the stress-strain relationship on $15 \mathrm{~cm}$ x $30 \mathrm{~cm}$ cylindrical concrete specimens, which treated in the form of a W/B ratio, silica fume, and steel fiber content variations. It can conclude that: In testing with W/B ratio and silica-fume content variations, the elastic modulus of concrete tends to decrease as the effect of increased water content and silica fume content. While testing with differences in steel fiber content, the modulus of elasticity tends to increase. Behavior stress-strain relationships in testing with variations in $\mathrm{W} / \mathrm{B}$ ratio tend to be closer to the equation proposed by Desay \& Khrisnan. While for the results of testing with changes in silica fume content and steel fiber content, it appears that behavior tends to be linear, the use of the Hognestaad equation and the Desay Khrisnan equation do not meet. 


\section{ACKNOWLEDGMENT}

Authors wishing to acknowledge to the technical staff of the structural laboratory of The Civil Engineering Department of Brawijaya University and financial support from the Indonesia Government to fulfill the research.

\section{REFERENCES}

[1] A. S. Arya and A. Agarwal, Multi-Hazard Resistant New Construction or Reconstruction of BPL Houses in Flood-Prone Alluvial Areas. 2008.

[2] NEHRP Consultants Joint Venture, "Program Plan for the Development of Collapse Assessment and Mitigation Strategies for Existing Reinforced Concrete Buildings," Nist Gcr 10-917-7, p. 100, 2010.

[3] ACI 363R-10, Report on High-Strength Concrete. 2010.

[4] ACI 363.2R-11, Guide to Quality Control and Assurance of HighStrength Concrete. 2011.

[5] ACI 544.1R-96, State-of-the-Art Report on Fiber Reinforced Concrete, vol. 96. Washington, D.C.: American Concrete Institute, 1997.

[6] P. Kmiecik and M. Kaminski, "Modelling of reinforced concrete structures and composite structures with concrete strength degradation taken into consideration," Arch. Civ. Mech. Eng., vol. XI, no. 3, pp. 623-636, 2011

[7] E. Hognestad, "A Study of Combined Bending and Axial Load in Reinforced Concrete Members," Bull. Ser. No. 399, p. 128, 1951.

[8] D. Moldovan and C. Magureanu, "Stress-Strain Diagram for High Strength Concrete Elements in Flexure," in 3rd International Conference Advanced Composite Materials Engineering, 2010, no. October, pp. 4-8
[9] J. D. Carreira and K.-H. Chu, "Stress-Strain Relationship for Plain Concrete in Compression," ACI J. Proc., vol. 82, no. 6, pp. 797-804, 1985.

[10] ASTM E6-07, Standard Terminology Relating to Methods of Mechanical Testing. 2007.

[11] ASTM C 469-02, Standard Test Method for Static Modulus of Elasticity and Poisson's Ratio of Concrete in Compression. Washington, D.C.: American Society for Testing and Materials (ASTM), 2002.

[12] ACI 211.1-91, Standard Practice for Selecting Proportions for Normal Heavyweight, and Mass Concrete (ACI 211.1-91) Reapproved 1997. Washington, D.C.: American Concrete Institute, 1997.

[13] SNI 7656:2012, Tata cara pemilihan campuran untuk beton normal, beton berat dan beton massa. Jakarta: Badan Standardisasi Nasional BSN, 2012.

[14] ASTM C 39/C39M-03, Standard Test Method for Compressive Strength of Cylindrical Concrete Specimens. Washington, D.C.: American Society for Testing and Materials (ASTM), 2003.

[15] SNI 03-1974-1990, Metode pengujian kuat tekan beton. Badan Standardisasi Nasional - BSN, 1990.

[16] Bekaert, "Dramix@ 3D 80/60 BG Data Sheet," Dramix Data Sheet. p. $1,2012$.

[17] Bekaert, Dramix Reinforcing the future. NV Bekaert SA, 2012

[18] ACI 363R-10, Report on High-Strength Concrete. 2010.

[19] B. Graybeal and M. Davis, "Cylinder or Cube Strength Testing of 80 t0 $200 \mathrm{MPa}$ Ultra-High-Performance Fiber-Reinforced-Concrete," ACI Mater. J. vol. 105, no. November/December, pp. 603-609, 2008.

[20] T. Noguchi, F. Tomosawa, K. M. Nemati, B. M. Chiaia, and A. R. Fantilli, "A practical equation for the elastic modulus of concrete," ACI Struct. J. vol. 106, no. 5, pp. 690-696, 2009. 